This item was submitted to Loughborough's Research Repository by the author.

Items in Figshare are protected by copyright, with all rights reserved, unless otherwise indicated.

\title{
Income inequality, fiscal stimuli and political (in)stability
}

PLEASE CITE THE PUBLISHED VERSION

http://dx.doi.org/10.1007/s10797-016-9428-x

PUBLISHER

(C) Springer

VERSION

AM (Accepted Manuscript)

\section{PUBLISHER STATEMENT}

This work is made available according to the conditions of the Creative Commons Attribution-NonCommercialNoDerivatives 4.0 International (CC BY-NC-ND 4.0) licence. Full details of this licence are available at: https://creativecommons.org/licenses/by-nc-nd/4.0/

\section{LICENCE}

CC BY-NC-ND 4.0

\section{REPOSITORY RECORD}

Agnello, Luca, Vitor Castro, Joao Tovar Jalles, and Ricardo M. Sousa. 2019. "Income Inequality, Fiscal Stimuli and Political (in)stability". figshare. https://hdl.handle.net/2134/24127. 


\title{
Income Inequality, Fiscal Stimuli and Political (In)Stability"
}

\author{
Luca Agnello $^{\#}$ Vitor Castro ${ }^{ \pm}$João Tovar Jalles ${ }^{+}$Ricardo M. Sousa
}

\begin{abstract}
Using data for a large panel of countries, this paper investigates the role played by income inequality and fiscal stimuli episodes in shaping the likelihood of political stability. By means of Tobit estimations, we show that a rise in inequality increases the probability of government crises. However, such adverse distributional effect is reduced when expansionary or increasingly expansionary fiscal stimuli episodes or successful fiscal stimuli programs are put in place.
\end{abstract}

JEL: Income distribution, fiscal stimuli, expansionary policies, political environment, institutional quality, Tobit regression.

Keywords: H63, G01, G15.

\footnotetext{
Castro and Sousa acknowledge that this work has been financed by Operational Programme for Competitiveness Factors - COMPETE and by National Funds through the FCT - Portuguese Foundation for Science and Technology within the remit of the project "FCOMP-01-0124-FEDER-037268 (PEstC/EGE/UI3182/2013)". Castro also wishes to thank the financial support provided by the Portuguese Foundation for Science and Technology under the research grant SFRH/BSAB/113588/2015 (partially funded by COMPETE, QREN and FEDER).

\# University of Palermo, Department of Economics, Business and Statistics (SEAS), Viale delle Scienze, 90128 Palermo, Italy. Email: luca.agnello01@unipa.it.

${ }^{ \pm}$University of Coimbra, Faculty of Economics, Av. Dias da Silva, 165, 3004-512 - Coimbra, Portugal; University of Minho, Economic Policies Research Unit (NIPE), Campus of Gualtar, 4710-057 - Braga, Portugal. Email: vcastro@fe.uc.pt.

${ }^{+}$Centre for Globalization and Governance, Nova School of Business and Economics, Campus Campolide, Lisbon, 1099-032 Portugal. Email: joaojalles@gmail.com.

${ }^{\$}$ University of Minho, Department of Economics and Economic Policies Research Unit (NIPE), Campus of Gualtar, 4710-057 - Braga, Portugal; London School of Economics and Political Science, LSE Alumni Association, Hougthton Street, London WC2A 2AE, United Kingdom. E-mails: rjsousa@eeg.uminho.pt, rjsousa@alumni.lse.ac.uk.
} 


\section{Introduction}

Income inequality is a major source of political instability. Yet, in the aftermath of the Global Financial Crisis of 2008-2009, many governments implemented large fiscal stimuli measures, which were subsequently reversed as concerns about the lack of sustainability of public finances started accumulating.

Moreover, despite some recent advances on the assessment of the relationship between fiscal policy and income inequality (Agnello and Sousa, 2014; Furceri et al., 2015), our understanding about the effects of a widening of the income gap and the use of discretionary fiscal policy actions on the occurrence of government crises is still far from clear cut.

Additionally, it is well-known that fiscally constrained governments tend to become less popular when they implement fiscal consolidation programs, especially, in countries with a strong income inequality. However, if fiscal adjustments are perceived as necessary and contribute to narrowing the income gap, the impact of inequality on political stability might be dampened. Thus, this paper aims at contributing to this discussion from an empirical perspective.

Our results show that rising income inequality makes government crises more likely to occur. Additionally, governments that implement fiscal stimuli are more likely to avoid the political unrest associated with an uneven distribution of income when those programs are successful in the sense of being followed by a large reduction of the debt-to-GDP ratio. Yet, such measures need to be increasingly expansionary to reduce the prospects of government crises in a significant manner.

Moreover, some features of incumbent legislature (i.e. whether there is a parliamentary majority or a coalition in power), a few characteristics of the political system (such as, the durability of the regime or the degree of competitiveness) and the level of democracy appear to be key for political stability.

In what follows, Section 2 describes the related literature and our main contribution to it. Section 3 presents the econometric methodology and the data used in the analysis. Section 4 provides the empirical findings. Section 5 discusses the major conclusions.

\section{An overview of the related literature: where do we stand and what do we add to it?}

The research on the linkages between political instability and real economic activity typically shows that poor growth has a detrimental effect of the probability of re-election of incumbent government in democratic regimes or tends to increase the likelihood of coups in dictatorships and military regimes, thus creating incentives for policymakers to implement 
sub-optimal policies (Kramer, 1971; Londregan and Poole, 1990). More political instability may also be associated with lower growth in the context of weak human capital accumulation or productivity growth (Aisen and Veiga, 2013). ${ }^{1}$

Another strand of the literature focuses on the joint dynamics of political instability and inflation. For example, Paldam (1987) shows that, in Latin America, there is a significant relationship between the likelihood of military regimes and the inflation rate, but only a few regimes survive inflationary crises. The empirical evidence provided by Aisen and Veiga (2008a, 2008b) also suggests that more political instability is associated with a high level or volatility of inflation, but this link is particularly strong when financing conditions are limited and there is a lack of central bank independence.

A third line of investigation looks into the impact of the institutional framework on political instability. In this context, more fragmented parliamentary systems are seen as a cause for less government stability (Taylor and Herman, 1971).

Given the current start of the art, it is worth highlighting that only a few works investigate the link between political instability and income inequality. Alesina and Perotti (1996) use data for 70 countries over the period 1960-1985 and show that income inequality increases the probability of government crises, because it generates social discontent. From an historical perspective, the authors note that several South East Asian countries - notably, the "four dragons" (i.e. Hong Hong, Singapore, South Korea and Taiwan) -, have been politically stable since the Second World War as a result of land reforms that reduced the income gap and the wealth inequality. In contrast, Latin American countries suffered from a more political instability as a consequence of a very unequal income distribution. Similarly, for a sample of 131 countries over a the period 1960-1995, Posner (1997) finds that average incomes in a society and, to a lesser extent, income equality are effective instruments to promote political stability. And, using data for a panel of 18 Latin American countries over the period 1971-2000, Blanco and Grier (2009) uncovers an inverted U-shaped effect of income inequality on political instability.

Moreover, despite the renewed attention on the impact of large fiscal adjustments on growth (Lambertini and Tavares, 2007), a detailed assessment of the effects of fiscal stimuli on political stability has not been conducted so far. Indeed, the related pieces of research have investigated how fiscal retrenchments affect the lack of political stability instead, and

\footnotetext{
${ }^{1}$ For instance, Martins and Veiga (2014) find that the size of the government (as a percentage of GDP) has a nonlinear impact on human development, with the effect being particularly large in developed economies and high-income countries.
} 
concluded about the relevance of: (i) fiscal austerity measures (Paldam, 1987); (ii) IMF stabilisation programs (Haggard et al., 1995); (iii) political cycles (Rogoff and Sibert, 1988; Alesina et al., 1998); and (iv) the cabinet ideology (i.e. left- versus right-wing) (Tavares, 2004).

From a slightly different perspective, Agnello and Sousa (2013) emphasize that fiscal prudence is crucial for economic prosperity. Agnello et al. (2013) stress that a sound macrofiscal environment is key for the success of fiscal consolidations, and Cafiso and Cellini (2014) show that tax-based fiscal consolidation programs are more detrimental for the dynamics of the public debt-to-GDP ratio than spending-based fiscal consolidations.

We contribute to the existing literature as follows. First, we specifically test for the existence of a "direct" link between fiscal stimuli, income inequality and political instability (as proxied by government crisis episodes). The idea is to assess whether income equality and discretionary expansionary fiscal policies can be regarded as effective instruments to promote political stability.

Second, given the strong relationship between income inequality and fiscal adjustment programs (Agnello and Sousa, 2014; Furceri et al., 2015), we investigate whether the use of expansionary fiscal policy discretion can be though as a transmission mechanism via which income inequality affects political stability (i.e. the "indirect" link). To the extent that expansionary fiscal programs are perceived to have positive wealth and redistributive effects (by reducing post-tax income inequality), they can also promote government stability.

Finally, because of the crucial role played by the composition of fiscal adjustments (Alesina and Ardagna, 2010), we identify several measures of fiscal stimuli with the aim of assessing their impact on political stability. These are avenues of research that previous theoretical and empirical works have not fully addressed. Yet, they are important dimensions to be considered for a better understanding of the relationship between income inequality, fiscal stimuli and political (in)stability. With the current paper, we aim at filling these gaps.

\section{Methodology and Data}

\subsection{Econometric Model}

We start by analysing the relationship between income inequality, fiscal stimuli episodes and government stability by estimating the following panel data model:

$$
\text { Gov Crisis }_{i, t}=\alpha+\lambda \text { Gini }_{i, t}+\phi F_{i, t}+\beta Y_{i, t}+\varepsilon_{i, t},
$$


where GovCrisis $s_{i, t}$ denotes, for each country $i$ at time $t$ included in the sample, our proxy of government instability, Gini $i_{i, t}$ denotes the income inequality index, $F_{i, t}$ is a binary variable that takes the value of one when a specific fiscal stimuli episode occurs, and zero otherwise, and $Y_{i, t}$ is a variable that tracks the dynamics of real economic activity, namely, the real GDP growth rate.

Next, we check whether the effects of income inequality on government stability change during periods of fiscal stimuli episodes, i.e. we look at the interaction between income inequality and fiscal stimuli by running the following regression:

$$
\text { GovCrisis }_{i, t}=\alpha+\lambda \operatorname{Gini}_{i, t}+\phi F_{i, t}+\theta \operatorname{Gini}_{i, t} \cdot F_{i, t}+\beta Y_{i, t}+\varepsilon_{i, t} .
$$

Given that the empirical evidence suggests that fiscal consolidations tend to widen the income gap (Agnello and Sousa, 2014; Furceri et al., 2015), we expect that the impact of inequality on government stability, conditional on the implementation of fiscal stimuli, is dampened.

Finally, we extend the baseline model to include a set of control variables for the political and the institutional frameworks, $\boldsymbol{X}_{i, t}$. We follow the same procedure as before: we start by estimating the direct effect of each variable; then, we allow for the interaction between inequality and fiscal stimuli. Thus, we regress the following models:

$$
\begin{aligned}
& \text { GovCrisis }_{i, t}=\alpha+\lambda \text { Gini }_{i, t}+\phi F_{i, t}+\beta Y_{i, t}+\gamma \mathbf{X}_{i, t}+\varepsilon_{i, t}, \\
& \text { GovCrisis }_{i, t}=\alpha+\lambda \operatorname{Gini}_{i, t}+\phi F_{i, t}+\theta G i n i_{i, t} \cdot F_{i, t}+\beta Y_{i, t}+\gamma \mathbf{X}_{i, t}+\varepsilon_{i, t} \text {. }
\end{aligned}
$$

Given the specific nature of our dependent variable (see section 3.2), all regressions are fitted using a Tobit model and a maximum likelihood estimator (Miranda and RabeHesketh, 2006; Finlay and Magnusson, 2009). In particular, because the government instability variable is bounded by zero from below and the number of cases in which it takes the value of "zero" is especially large compared to the number of cases in which it takes a positive value, the use of an OLS estimator or limited dependent variable models (such as, the probit or the logit) would render biased estimates. In fact, there would be a downward-bias in the estimate of the slope coefficients and an upward-bias in the estimate of the intercept associated with these frameworks. The tobit regression overcomes the difficulties associated with such econometric methodologies. Finally, to account for potential reversal causality between variables GovCrisis int $_{\text {and }} Y_{i, t}$, the latter is instrumented using its own first two lags. 


\subsection{Data}

Our dataset consists of a large panel of 157 countries between 1960 and 2010 for which we are able to identify fiscal stimuli episodes. ${ }^{2}$

The dependent variable, GovCrisis $i_{i, t}$, is Government Crisis, which counts the number of "... any rapidly developing situation that threatens to bring the downfall of the present regime - excluding situations of revolt aimed at such overthrow." (Banks and Wilson, 2013). This variable is provided by the Cross-National Time-Series Data Archive (CNTS), where it is labelled as "S17F4 Government Crises". ${ }^{3}$

Net (i.e. post-tax, post-transfer) income Gini inequality index data comes from the Standardized World Income Inequality Database (SWIID). This measure accounts for the concept, definition of income and recipient unit, tracks different points in the income distribution and measures the level and the trend of income inequality in a harmonized manner (see Nolan et al. (2011) for further details). Moreover, it covers a large number of countries (namely, 153) and a long period of time (annual data exists in an unbalanced form since 1960), thus, easing comparability across countries and over time (Solt, 2009). The SWIID employs a transparent procedure, whereby it combines information about the Gini index from the World Income Inequality Database (WIID) and from the Luxembourg Income Study (LIS). Then, the data are standardized via a missing-data statistical algorithm. We focus on the net of taxes' income definition instead of the gross income definition in order to capture the differences in cross-national redistributive policies (see Ostry et al. (2014)), which may lead to significant gaps between inequality in gross and net income.

The cyclically adjusted budget balance (CAPB) is obtained from the IMF's WEO and is computed using the statistical approach proposed by Blanchard (1990). Public debt data

\footnotetext{
${ }^{2}$ In order to save space, the full list of countries included in the analysis is not reported in the paper. However, it is available from the authors upon request. The presence of missing values for several variables and the limited time span of fiscal variables, especially, in the case of developing countries, reduces the number of countries included in each model specification. Please refer to Table A.1 in the Appendix for the descriptive statistics of the variables used in this study.

3 The CNTS dataset contains a wide range of domestic conflict event rata (such as, anti-government demonstrations, assassinations, general strikes, guerrilla warfare, major government crises, purges, riots and revolutions), legislative process data (namely, the competitiveness of nominating process, the effectiveness and the size of legislature, the number of seats of the largest party in legislature, and the party coalitions and legitimacy), political data (such as, the changes in effective executive, the degree of parliamentary responsibility, the legislative effectiveness and selection, the number of coups d'Etat, the number of legislative elections, the number of major constitutional changes, the number of major cabinet changes, the party fractionalization index, the size of cabinet and the type of regime). Due to data availability and country coverage, we use Government Crisis as our measure of political instability.
} 
come from the Historical Public Debt Database gathered by the Fiscal Affairs Department of the IMF (Ali Abbas et al., 2011). Fiscal stimuli episodes are defined as follows:

- Fiscal stimulus. A period of fiscal stimulus corresponds to a year in which the CAPB deteriorates by at least 1.5 per cent of GDP. This definition follows the work of Alesina and Ardagna (2010). The authors argue that the choice of such threshold allows one to rule out small, but prolonged over time, fiscal stimuli episodes and, thus, to focus on large, sharp and brief adjustments in the fiscal stance.

- Expansionary fiscal stimulus. It denotes a period of fiscal stimulus followed by a positive GDP growth for two consecutive years. Thus, like Alesina and Ardagna (2010), we allow for a reasonable time lag in the generation of real effects by fiscal stimuli programs.

- Increasingly expansionary fiscal stimulus. It refers to a period of fiscal stimulus followed by an increasing GDP for two consecutive years. Compared to the previous one, this definition allows to account for a sustained growth path.

- Successful (Unsuccessful) fiscal stimulus. It corresponds to a period of fiscal stimulus followed by the cumulative reduction of the debt to GDP ratio greater (smaller) than 4.5 percentage points over two consecutive years after the beginning of a fiscal stimulus, which is in line with the definition presented in the work of Alesina and Ardagna (2010).

At this point, a caveat should be made. We are aware that while the Alesina and Ardagna (2010)'s approach is easy to apply, it is known that it might detect episodes that are not really a fiscal stimulus. ${ }^{4}$ This is why authors as Romer and Romer (2010) and Devries et al. (2011) embark in the narrative approach. ${ }^{5}$ While the use of a narrative approach would be ideal, existing datasets only include the identification of fiscal consolidations, not fiscal expansions, and for a limited number of advanced economies. ${ }^{6}$ In addition, the literature addressing the identification of fiscal episodes is vast and has, for a long time, relied on changes in the CAPB. While some drawbacks surrounding this approach have been recently

\footnotetext{
${ }^{4}$ We thank an anonymous referee for raising this point.

5 Romer and Romer (2010) use a "narrative record" of budget laws, Congressional reports, executive branch documents and presidential speeches to identify the size, timing, and motivation for major tax policy actions. Devries et al. (2011) identify episodes of large fiscal adjustments by looking at IMF and OECD historical reports and checking what countries intended to do when the reports were published. This policy action-based approach makes use of descriptive historical facts that usually depict what happened to the public deficit in a particular period but do not go into the details of policymakers' intentions and discussions or congressional records.

${ }^{6}$ More specifically, it covers 17 OECD countries over the period 1978-2009.
} 
highlighted, it is the best one to cover a heterogeneous sample of 157 countries. $^{7}$ In face of some serious concerns, an alternative "narrative approach" was developed, which relies on the identification of fiscal episodes based on concrete policy decisions. Proponents of this approach argue that the estimated size of the fiscal measures during the identified episodes have the advantage of not being affected by the cycle (since their construction is bottom up), can minimize identification problems, and are unlikely to embody risks of reverse causation (Guajardo et al., 2014). However, the narrative approach could also have some limitations. ${ }^{8}$

The variable used to control for the economic environment, real GDP growth rate, was collected from the World Economic Outlook (WEO) of the International Monetary Fund (IMF).

The set of institutional variables $(\mathbf{X})$ is obtained from the World Bank's Database of Political Institutions (DPI), the Polity IV Database (Polity IV) and the CNTS and includes:

- military (DPI): this dummy variable takes the value of one if the Chief Executive is a military officer, and zero otherwise.

- stabs (DPI): it provides information about the veto points in the decision making process and the constraints that face by governments in the course of policy implementation by counting the percentage of veto players who drop from the government in a specific year.

- system (DPI): it takes the value of zero in the case of a presidential system, the value of one in the case of an Assembly-elected presidential system, and the value of two in the case of a parliamentary system.

- govfrac (Polity IV): it measures the probability that two deputies picked at random from among the government parties will be of different parties, thus, capturing the degree of government fragmentation.

- polity2 (Polity IV): it describes how democratic a country is by subtracting the country's score in an "Autocracy" index from its score in a "Democracy" index. This generates a polity scale ranging from -10 (strongly autocratic) to +10 (strongly democratic).

- durable (DPI): it counts the number of years that a cabinet has been in power, up to the current year. A fall of the cabinet in its first year in power is counted as one,

\footnotetext{
7 The statistical approach may generate an upward bias towards evidence corroborating non-Keynesian effects (Afonso and Jalles, 2014). Non-policy factors (including price fluctuations) can affect the computation of CAPB. Additionally, fiscal measures include the discretionary reaction to the dynamics of real economic activity.

${ }^{8}$ In particular, it largely relies on judgment calls, and it may not entirely eliminate endogeneity problems (that is, fiscal policy reacting to output performance and not the other way around).
} 
and each time the government terminates the variable is reset to one in the year after the termination.

- polcomp (Polity IV): it tracks the degree of political competition that the incumbent is expected to face in the next election in account of the policy decisions made over the administration cycle.

- $y r s o f f c$ (DPI): it is simply the number of years that the chief executive has been in office.

- $\quad$ maj (DPI): this dummy variable takes the value of one if the cabinet has majority support in parliament, and zero otherwise.

- party_coal (DPI): this dummy variable is equal to one if a coalition cabinet (including ministers from two or more parties) is in power, and zero otherwise.

\section{Empirical Results}

\subsection{Political Instability, Inequality and Fiscal Stimuli}

We begin by analysing the effect of income inequality and fiscal stimuli on the likelihood of government crisis episodes. Thus, first, we estimate the baseline model; and, then, we move to the analysis of the interaction effects. In both cases, we take into account the heterogeneity of the countries considered in the sample, by distinguishing between developed and developing/emerging countries.

Table 1 reports the estimated coefficients for our baseline model. In censored frameworks (such as, the tobit model) and, in particular, for explanatory variables that are binary (such as, our fiscal stimuli dummy variables), the partial derivatives of the regression function do not have a simple interpretation. ${ }^{9}$ However, for continuous variables (such as, most of the controls included in our specifications), a straightforward way to obtain the marginal effects in the tobit model is simply to multiply each estimated coefficient by the fitted probability of the model. Therefore, we can rely our inference on the direct analysis of the estimated coefficients, as their signs are the same as those of the resulting marginal effects evaluated at the means of the control variables.

Starting by the influence of the economic environment, our empirical findings show that economic growth contributes to stable legislature, corroborating the findings of Aisen and Veiga (2008a, 2008b). In light of the magnitude of the coefficient associated with real GDP

\footnotetext{
${ }^{9}$ See Greene (2012, pp. 848-850).
} 
growth, the baseline model suggests that the performance of the economy is, perhaps, the most important determinant of political stability.

Moving to the analysis of the impact of inequality on political instability, our results clearly suggest that when the income gap increases, the number of government crisis rises. This, in turn, highlights that countries which fail to address the problem of inequality in their income distribution are more susceptible to face social polarization and, hence, generate an unstable political environment.

\section{[ INSERT TABLE 1 HERE. ]}

Next, we consider the different typologies of fiscal stimuli episodes as detailed in Section 3.2 above, namely: (i) fiscal stimuli, (ii) increasingly expansionary fiscal stimuli, (iii) expansionary fiscal stimuli, (iv) successful fiscal stimuli, and (v) unsuccessful fiscal stimuli. It can be seen that episodes of fiscal stimuli are not associated with more unstable political environments per se. In fact, results suggest that fiscal stimuli episodes do not significantly reduce the occurrence of government crises. This can occur since the effect of fiscal stimuli may not be independent from a given country's level of income or a given country's level of income distribution. We will explore this issue next. First, we check whether there are significant differences between developed (OECD) and developing and emerging (nonOECD) countries (Table 2); then, we account for the interactions between income inequality and the fiscal stimuli variables (Table 3); a separate analysis of the models allowing for the interaction terms will also be performed for the two separate sub-samples of OECD and nonOECD countries (Table 4).

Results reported in Table 2 for the OECD and non-OECD countries are in line with the findings obtained for the whole sample, but slightly weaker as the number of observations is smaller in each sub-sample. In what concerns the fiscal variables, no statistically significant effects are found in either of the cases. This means that heterogeneity is not driving the impact of fiscal stimuli on the occurrence of government crises. However, while the economic environment is more important for the non-OECD sub-sample, income inequality plays a major role on political instability in the group of richer countries.

\section{[ INSERT TABLE 2 HERE. ]}

In the next set of regressions, we condition the effect of inequality and fiscal stimuli episodes on political instability by interacting the (net income) Gini inequality index with the various fiscal stimuli variables and assess whether their impact on a government crisis is influenced by the way they inter-relate. 
Results are summarized in Table 3 and show that despite the interaction effects, income inequality remains having a statistically significant impact on political instability. Even though this effect is not significantly altered during the implementation of fiscal stimuli programs (see column 1), when they are increasingly expansionary, the detrimental impact that income inequality has on political instability is abated (see column 2). However, the implementation of that kind of programs seems to cause an increase in the overall degree of political instability. Political interests could be driving this result. On the contrary, if fiscal stimuli programs are successful, they seem to promote a greater degree of consensus among the political agents and political instability is reduced. Nevertheless, some economic agents seem to benefit more from that "success", as the effect of inequality is increased when successful fiscal stimuli programs are implemented (see column 4). Regarding the other king of programs, no statistically significant effects are found.

All in all, these findings interestingly suggest that in countries where income distribution is uneven, governments implementing fiscal stimuli programs are more likely to avoid political instability if they end up being successful. Yet, such programs need to be increasingly expansionary (in the sense that they generate positive sustainable growth) to be able to significantly reduce the likelihood of government crises.

\section{[ INSERT TABLE 3 HERE. ]}

When accounting for the sample's cross-section heterogeneity (OECD versus nonOECD countries) in our analysis, we confirm that successful fiscal stimuli programs are also "successful" in reducing government crises. Results reported in Table 4 also show that in the group of OECD countries, this effect is reinforced if the program is expansionary.

\section{[ INSERT TABLE 4 HERE. ]}

\subsection{Political Instability and the Role of Political and Institutional Controls}

Table 5 reports results accounting for the role of the additional political and institutional controls. With the inclusion of this set of variables, the impact of the economic environment is less significant, but income inequality keeps driving the increase in the number of government crises.

Regarding the institutional variables, we observe that the percentage of veto players who drop from the government (stabs), the number of years that a cabinet has been in power (durable), the level of political competition (polcomp) and whether the government consists of a coalition or not (party_coal), exert a statistically significant impact on government crises. These variables have a statistically significant negative effect on the number of government 
crises, in line with conventional wisdom. In particular, the regime durability (durable) reduces the number of government crises and the level of political competition (polcomp) seems to pave the ground for more political stability. On the contrary, parliamentary systems (system) and more democratic countries (polity2) seem to ignite government crises. In what concerns the political regime (polity2), evidence suggests that the more democratic a regime is, the more political instability the country will face.

As for other controls, the fact of a government has a majority of seats in the parliament (maj) has only a marginally weak negative effect on political instability, but military regimes (military), the level of government fractionalization (govfrac) and the number of years in office of the chief executive (yrsoffc) have not proved to have a significant impact on the number of government crisis.

Despite the inclusion of political and institutional controls, episodes of fiscal stimuli are not influencing the political environment: overall, fiscal stimuli episodes do not significantly reduce the occurrence of government crises. This evidence is not only observed for the whole sample, but also in the separate sub-sample analysis for OECD and non-OECD countries (see Table 6). However, income inequality is still driving political instability mainly in the group of OECD countries. In what concerns to the effects of the institutional variables, some differences are observed. While political instability increases with the degree of democracy in both groups, parliamentary systems are only relevant in the case of OECD countries. The percentage of veto players who drop from the government and regime durability are beneficial for political stability also only in this group. On the contrary, political competition and party coalitions have proven to be significant for the number of government crises only in the non-OECD sub-sample. Moreover, majority governments and the number of years in office of the chief executive are negatively correlated with government crises in this sub-sample, while military regimes have the same effect as in OECD countries.

\section{[ INSERT TABLE 5 HERE. ] \\ [ INSERT TABLE 6 HERE. ]}

As before, in the next set of regressions, we control for the interactions between the (net income) Gini inequality index and the various fiscal stimuli variables. Results for the entire sample are reported in Table 7. In general, the empirical evidence remains unchanged for the economic, political and institutional variables, so we will focus the analysis on the inequality effects, fiscal variables and the respective interaction terms.

Regardless of the inclusion of the institutional controls, the positive effect of income inequality on the number of government crises remains highly statistically significant. This 
impact does not substantially change during the implementation of a particular fiscal stimuli program, but, as inferred before, if the program is increasingly expansionary, the negative effect of the Gini index on political instability is significantly abated (Column 2). The drawback of this effect is that the implementation of these programs ends up causing an increase in the overall level of political instability, unless the program turns out to be successful (Column 4). However, as found in the analysis without the institutional controllers, some people benefit more from that "success" than others, as the effect of inequality is increased when successful fiscal stimuli programs are implemented. Once again, no significant effects are found for the other types of programs.

\section{[ INSERT TABLE 7 HERE. ]}

Table 8 shows the results for the separate sub-samples: OECD vs non-OECD. The main aspect to be emphasized here is that when we account for the sample's cross-section heterogeneity, we reach the same conclusion as before: successful fiscal stimuli programs are also "successful" in reducing the number of government crises.

[ INSERT TABLE 8 HERE. ]

\subsection{Regional Effects}

To shed some light on the potential linkages between geographical location and government crises, we split the sample in regional sub-samples:: Europe, North America, Asia-Pacific (APAC), Latin America and Africa.

The empirical results are reported in Tables 9-10. Overall, they show that income inequality exerts a very significant and positive impact on the number of episodes of government crises in both the European and North American set of countries, while the underlying economic environment has proven to be relevant only in the group of European countries. Moreover, our results confirm that expansionary and/or successful fiscal stimuli programs help promoting a more stable political framework in these two groups of countries. In the other three groups reported, no statistically significant results are found.

[ INSERT TABLE 9 HERE. ]

[ INSERT TABLE 10 HERE. ]

\section{Conclusion}

In this paper, we employed a panel of 157 countries over the period 1960-2010 to investigate how income inequality and fiscal stimuli affect episodes of government crisis. 
We found that political instability increases when inequality rises, especially in the case of OECD countries.

Our results also reveal that expansionary and increasingly expansionary fiscal stimuli can contribute to more political stability. Additionally, our findings suggest that in countries where income distribution is uneven, governments implementing fiscal stimuli programs are more likely to avoid political instability when those programs are successful. Yet, they need to be increasingly expansionary to be able to significantly reduce the prospects of government crises.

Additionally, we found that the existence of a coalition government, the regime durability, the degree of political competitiveness and the percentage of veto players who drop from the government reduce political instability, while the kind of the political system and the degree of democracy boosts the likelihood of government crises. Thus, our empirical evidence confirms the pivotal importance of the quality of political institutions as an "antidote" against government crises.

Finally, on the macroeconomic front, economic growth emerged as a crucial driver of political stability.

\section{References}

Afonso, A., Jalles, J.T., 2014. Assessing fiscal episodes. Economic Modeling, 37, 255-270.

Agnello, A., Castro, V., Sousa, R.M., 2013. What determines the duration of a fiscal consolidation program? Journal of International Money and Finance, 37, 113-134.

Agnello, A., Sousa, R.M., 2013. Political, institutional and economic factors underlying deficit volatility. Review of International Economics, 21(4), 719-732.

Agnello, L., Sousa, R.M., 2014. How does fiscal consolidation impact on income inequality? Review of Income and Wealth, 60(4), 702-726.

Aisen, A., Veiga, F.J., 2008a. The political economy of seigniorage. Journal of Development Economics, 87, 29-50.

Aisen, A., Veiga, F.J., 2008b. Political instability and inflation volatility. Public Choice, 135, 207-223.

Aisen, A., Veiga, F.J., 2013. How does political instability affect economic growth? European Journal of Political Economy, 29, 151 -167.

Alesina, A., Ardagna, S., 2010. Large changes in fiscal policy: Taxes versus spending. In: Brown, J. R. (Ed.). Tax Policy and the Economy, 24, National Bureau of Economic Research, University of Chicago Press, Chicago, IL, 35-68. 
Alesina, A, Perotti, R., 1996. Income distribution, political stability and investment. European Economic Review, 40(6), 1203-1228.

Alesina, A., Perotti, R., Tavares, J.A., 1998. The political economy of fiscal adjustments. Brookings Papers on Economic Activity, 29(1), 197-266.

Ali Abbas, S. M., Belhocine, N., El Ganainy, A., Horton, M., 2011. Historical patterns of public debt - Evidence from a new database. IMF Economic Review, 59, 717-742.

Banks, A.S., Wilson, K.A. 2013. Cross-National Time-Series Data Archive. Databanks International. Jerusalem, Israel.

Blanchard, O., 1990. Suggestions for a new set of fiscal indicators. Organisation for Economic Co-Operation and Development, OECD Economics Department Working Paper, No. 79.

Blanco, L., Grier, R., 2009. Long live democracy: The determinants of political instability in Latin America. Journal of Development Studies, 45(1), 76-95.

Cafiso, G., Cellini, R., 2014. Fiscal consolidations and public debt in Europe. International Tax and Public Finance, 21(4), 614-644.

Devries, P., Guajardo, J., Leigh, D., Pescatori, A., 2011. A new action based dataset of fiscal consolidation. International Monetary Fund, IMF Working Paper No. 128.

Furceri, D., Jalles, J.T., Loungani, P. 2015b. Fiscal consolidation and inequality in advanced economies: How robust is the link? In: IMF (ed.), Inequality and the role of fiscal policy: trends and policy options, IMF, Fiscal Affairs Department, Washington, DC, USA.

Finlay, K., Magnusson, L.M., 2009. Implementing weak-instrument robust tests for a general class of instrumental variables models. Stata Journal, 9, 398-421.

Greene, W., 2012. Econometric Analysis, $7^{\text {th }}$ Ed. Prentice Hall, Pearson Education. Boston, MA.

Guajardo, J., Leigh, D., Pescatori, A., 2014. Expansionary austerity? International evidence. Journal of the European Economic Association, 12(4), 949-968.

Haggard, S., Lafay, J.D., Morrisson, C., 1995. The political feasibility of adjustment in developing countries. OECD, Development Centre Studies, Paris: France.

Kramer, G., 1971. Short term fluctuations in U.S. voting behavior, 1896-1964. American Political Science Review, 65, 131-143.

Lambertini, L., Tavares, J.A., 2007. Exchange rates and fiscal adjustments: Evidence from the OECD and implications for the EMU. Contributions in Macroeconomics, 5(1), 1-30.

Londregan, J.B., Poole, K.T., 1990. Poverty, the coup trap, and the seizure of executive power. World Politics, 42(2), 151-183. 
Martins, S., Veiga, F.J., 2014. Government size, composition of public expenditure, and economic development. International Tax and Public Finance, 21(4), 578-597.

Miranda, A., Rabe-Hesketh, S., 2006. Maximum likelihood estimation of endogenous switching and sample selection models for binary, ordinal, and count variables. Stata Journal, 6, 285-308.

Nolan, B., Marx, I., Salverda, W., 2011. Comparable indicators of inequality across countries. GINI Discussion Paper No. 9, 2011.

Ostry J., Berg, A., Tsangarides, C., 2014. Redistribution, inequality, and growth. IMF Staff Discussion Note, February.

Paldam, M., 1987. Inflation and political instability in eight Latin American countries 194683. Public Choice, 52, 143-168.

Posner, R.A., 1997. Equality, wealth, and political stability. Journal of Law, Economics \& Organization, 13(2), 344-365.

Rogoff, K., Sibert, A., 1988. Elections and macroeconomic policy cycles. Review of Economic Studies, 55, 1-16.

Romer, D., Romer, C., 2010. The macroeconomic effects of tax changes: Estimates based on a new measure of fiscal shocks. American Economic Review, 100(3), 763-801.

Solt, F., 2009. Standardizing the World Income Inequality Database. Social Science Quarterly, 90(2), 231-242.

Tavares, J., 2004. Does right or left matter? Cabinets, credibility and fiscal adjustments. Journal of Public Economics, 88(12), 2447-2468.

Taylor, M., Herman, V.M., 1971. Party systems and government stability. American Political Science Review, 65(1), 28-37. 


\section{List of Tables}

Table 1: Political instability, inequality and fiscal stimuli.

\begin{tabular}{|c|c|c|c|c|c|}
\hline & (1) & (2) & (3) & (4) & (5) \\
\hline GDP growth rate & $\begin{array}{c}-0.1471^{\star *} \\
{[0.074]}\end{array}$ & $\begin{array}{c}-0.1436^{\star *} \\
{[0.068]}\end{array}$ & $\begin{array}{c}-0.1423^{\star *} \\
{[0.071]}\end{array}$ & $\begin{array}{c}-0.1453^{\star *} \\
{[0.069]}\end{array}$ & $\begin{array}{c}-0.1466^{\star *} \\
{[0.072]}\end{array}$ \\
\hline Inequality & $\begin{array}{c}0.0231^{* *} \\
{[0.010]}\end{array}$ & $\begin{array}{c}0.0228^{* *} \\
{[0.010]}\end{array}$ & $\begin{array}{c}0.0227^{* *} \\
{[0.010]}\end{array}$ & $\begin{array}{c}0.0221^{* *} \\
{[0.010]}\end{array}$ & $\begin{array}{c}0.0226^{\star *} \\
{[0.010]}\end{array}$ \\
\hline fiscal stimuli & $\begin{array}{l}-0.1263 \\
{[0.263]}\end{array}$ & & & & \\
\hline \multirow{2}{*}{$\begin{array}{l}\text { increasingly expansionary fiscal } \\
\text { stimuli }\end{array}$} & & -0.2062 & & & \\
\hline & & {$[0.375]$} & & & \\
\hline expansionary fiscal stimuli & & & $\begin{array}{l}-0.0345 \\
{[0.249]}\end{array}$ & & \\
\hline successful fiscal stimuli & & & & $\begin{array}{l}0.1416 \\
{[0.354]}\end{array}$ & \\
\hline unsuccesful fiscal stimuli & & & & & $\begin{array}{l}-0.2259 \\
{[02831}\end{array}$ \\
\hline Constant & $\begin{array}{c}-2.8792^{* * *} \\
{[0.473]}\end{array}$ & $\begin{array}{c}-2.8884^{* * *} \\
{[0.462]}\end{array}$ & $\begin{array}{c}-2.8949^{* * *} \\
{[0.468]}\end{array}$ & $\begin{array}{c}-2.8964^{* * *} \\
{[0.464]}\end{array}$ & $\begin{array}{c}-2.8535^{\star * *} \\
{[0.481]}\end{array}$ \\
\hline Observations & 1,260 & 1,260 & 1,260 & 1,249 & 1,252 \\
\hline & 0.472 & 0.465 & 0.449 & 0.526 & 0.436 \\
\hline Prob $>\chi^{2}$ & 0.492 & 0.495 & 0.503 & 0.468 & 0.509 \\
\hline
\end{tabular}

Note: IV estimation of Tobit model. Wald test of exogeneity is reported at the bottom of the table. Robust standard errors in brackets. ${ }^{* *} p<0.01,{ }^{* *} p<0.05,{ }^{*} p<0.1$. 
Table 2: Political instability, inequality and fiscal stimuli: OECD versus non-OECD countries.

\begin{tabular}{|c|c|c|c|c|c|c|c|c|c|c|}
\hline & \multicolumn{5}{|c|}{ OECD countries } & \multicolumn{5}{|c|}{ non-OECD countries } \\
\hline & (1) & (2) & (3) & (4) & (5) & (1) & (2) & (3) & (4) & (5) \\
\hline GDP growth rate & -0.2249 & -0.2065 & -0.2106 & -0.2028 & -0.2264 & $-0.1378^{*}$ & $-0.1383^{*}$ & $-0.1357^{*}$ & $-0.1345^{*}$ & $-0.1379^{*}$ \\
\hline & {$[0.179]$} & {$[0.162]$} & {$[0.167]$} & {$[0.154]$} & {$[0.184]$} & {$[0.081]$} & {$[0.076]$} & {$[0.078]$} & {$[0.078]$} & {$[0.078]$} \\
\hline Inequality & $0.0358^{*}$ & $0.0330^{*}$ & $0.0335^{*}$ & $0.0347^{*}$ & $0.0344^{*}$ & 0.0128 & 0.0125 & 0.0128 & 0.013 & 0.0115 \\
\hline & {$[0.020]$} & {$[0.020]$} & {$[0.020]$} & {$[0.020]$} & {$[0.020]$} & {$[0.017]$} & {$[0.017]$} & {$[0.017]$} & {$[0.017]$} & [0.017] \\
\hline fiscal stimuli & $\begin{array}{l}-0.3026 \\
{[0.530]}\end{array}$ & & & & & $\begin{array}{l}-0.1138 \\
{[0.307]}\end{array}$ & & & & \\
\hline increasingly expansionary fiscal stimuli & & $\begin{array}{l}0.2477 \\
{[0.730]}\end{array}$ & & & & & $\begin{array}{l}-0.4653 \\
{[0.427]}\end{array}$ & & & \\
\hline expansionary fiscal stimuli & & & $\begin{array}{l}-0.0548 \\
{[0.465]}\end{array}$ & & & & & $\begin{array}{c}-0.0834 \\
{[0.295]}\end{array}$ & & \\
\hline successful fiscal stimuli & & & & $\begin{array}{l}-0.4539 \\
{[0.766]}\end{array}$ & & & & & $\begin{array}{l}0.2313 \\
{[0.389]}\end{array}$ & \\
\hline unsuccesful fiscal stimuli & & & & & $\begin{array}{l}-0.2512 \\
{[0.574]}\end{array}$ & & & & & $\begin{array}{l}-0.3092 \\
{[0.334]}\end{array}$ \\
\hline Constant & $\begin{array}{c}-3.2593^{* * *} \\
{[0.735]}\end{array}$ & $\begin{array}{c}-3.2796^{* * *} \\
{[0.721]}\end{array}$ & $\begin{array}{c}-3.2666^{* * *} \\
{[0.721]} \\
\end{array}$ & $\begin{array}{c}-3.3192^{* * *} \\
{[0.725]}\end{array}$ & $\begin{array}{c}-3.2300^{* * *} \\
{[0.755]}\end{array}$ & $\begin{array}{c}-2.3414^{* * *} \\
{[0.826]}\end{array}$ & $\begin{array}{c}-2.3175^{\star * *} \\
{[0.810]}\end{array}$ & $\begin{array}{c}-2.3556^{\star * *} \\
{[0.816]}\end{array}$ & $\begin{array}{c}-2.4275^{\star * *} \\
{[0.832]}\end{array}$ & $\begin{array}{c}-2.2620^{* * *} \\
{[0.840]}\end{array}$ \\
\hline Observations & 571 & 571 & 571 & 571 & 571 & 689 & 689 & 689 & 678 & 681 \\
\hline$\chi^{2}$ & 0.0507 & 0.0599 & 0.0511 & 0.0299 & 0.0642 & 0.523 & 0.544 & 0.524 & 0.527 & 0.488 \\
\hline Prob $>\chi^{2}$ & 0.822 & 0.807 & 0.821 & 0.863 & 0.8 & 0.47 & 0.461 & 0.469 & 0.468 & 0.485 \\
\hline
\end{tabular}


Table 3: Interactions between inequality and fiscal stimuli.

\begin{tabular}{|c|c|c|c|c|c|}
\hline & (1) & (2) & (3) & (4) & (5) \\
\hline GDP growth rate & $\begin{array}{c}-0.1466^{\star *} \\
{[0.074]}\end{array}$ & $\begin{array}{c}-0.1360^{* *} \\
{[0.068]}\end{array}$ & $\begin{array}{c}-0.1420^{* *} \\
{[0.071]}\end{array}$ & $\begin{array}{c}-0.1424^{* *} \\
{[0.070]}\end{array}$ & $\begin{array}{c}-0.1456^{* *} \\
{[0.072]}\end{array}$ \\
\hline inequality & $\begin{array}{l}0.0196^{*} \\
{[0.011]}\end{array}$ & $\begin{array}{c}0.0274^{\star * *} \\
{[0.010]}\end{array}$ & $\begin{array}{l}0.0214^{*} \\
{[0.011]}\end{array}$ & $\begin{array}{l}0.0182^{*} \\
{[0.0101}\end{array}$ & $\begin{array}{c}0.0248^{\star *} \\
{[0.011]}\end{array}$ \\
\hline inequality $\mathrm{x}$ fiscal stimuli & $\begin{array}{l}0.0149 \\
{[0.020]}\end{array}$ & & & & \\
\hline fiscal stimuli & $\begin{array}{l}-0.7305 \\
{[0.867]}\end{array}$ & & & & \\
\hline inequality $\mathrm{x}$ increasingly expansionary fiscal stimuli & & $\begin{array}{c}-0.0617^{\star *} \\
{[0.030]}\end{array}$ & & & \\
\hline increasingly expansionary fiscal stimuli & & $\begin{array}{c}2.2682^{*} \\
{[1.273]}\end{array}$ & & & \\
\hline inequality $\mathrm{x}$ expansionary fiscal stimuli & & & $\begin{array}{l}0.0059 \\
{[0.021]}\end{array}$ & & \\
\hline expansionary fiscal stimuli & & & $\begin{array}{l}-0.2754 \\
{[0.873]}\end{array}$ & & \\
\hline inequality $x$ successful fiscal stimuli & & & & $\begin{array}{c}0.1141^{\star *} \\
{[0.048]}\end{array}$ & \\
\hline successful fiscal stimuli & & & & $\begin{array}{c}-5.1583^{* *} \\
{[2.303]}\end{array}$ & \\
\hline inequality $x$ unsuccessful fiscal stimuli & & & & & $\begin{array}{l}-0.0129 \\
{[0.022]}\end{array}$ \\
\hline unsuccesful fiscal stimuli & & & & & $\begin{array}{l}0.2808 \\
{[0.882]}\end{array}$ \\
\hline Constant & $\begin{array}{c}-2.7443^{\star * *} \\
{[0.520]}\end{array}$ & $\begin{array}{c}-3.0730^{\star * *} \\
{[0.482]}\end{array}$ & $\begin{array}{c}-2.8452^{\star * *} \\
{[0.515]}\end{array}$ & $\begin{array}{c}-2.7442^{\star * *} \\
{[0.471]}\end{array}$ & $\begin{array}{c}-2.9423^{\star \star *} \\
{[0.517]}\end{array}$ \\
\hline Observations & 1,260 & 1,260 & 1,260 & 1,249 & 1,252 \\
\hline$\chi^{2}$ & 0.467 & 0.344 & 0.442 & 0.445 & 0.416 \\
\hline Prob $>\chi^{2}$ & 0.494 & 0.558 & 0.506 & 0.505 & 0.519 \\
\hline
\end{tabular}

Note: IV estimation of Tobit model. Wald test of exogeneity is reported at the bottom of the table.

Robust standard errors in brackets. ${ }^{* * *} p<0.01,{ }^{* *} p<0.05,{ }^{*} p<0.1$. 
Table 4: Interactions between inequality and fiscal stimuli: OECD versus non-OECD countries.

\begin{tabular}{|c|c|c|c|c|c|c|c|c|c|c|}
\hline & \multicolumn{5}{|c|}{ OECD countries } & \multicolumn{5}{|c|}{ non-OECD countries } \\
\hline & $(1)$ & $(2)$ & $(3)$ & $(4)$ & $(5)$ & $(1)$ & $(2)$ & (3) & $(4)$ & $(5)$ \\
\hline GDP growth rate & $\begin{array}{c}-0.2249 \\
{[0.178]}\end{array}$ & $\begin{array}{c}-0.2032 \\
{[0.163]}\end{array}$ & $\begin{array}{c}-0.2035 \\
{[0.166]}\end{array}$ & $\begin{array}{l}-0.203 \\
{[0.154]}\end{array}$ & $\begin{array}{c}-0.2196 \\
{[0.185]}\end{array}$ & $\begin{array}{c}-0.1380^{*} \\
{[0.081]}\end{array}$ & $\begin{array}{c}-0.1290^{*} \\
{[0.076]}\end{array}$ & $\begin{array}{c}-0.1350^{*} \\
{[0.079]}\end{array}$ & $\begin{array}{c}-0.1355^{\star} \\
{[0.078]}\end{array}$ & $\begin{array}{c}-0.1332^{*} \\
{[0.078]}\end{array}$ \\
\hline inequality & $\begin{array}{l}0.0174 \\
{[0.025]}\end{array}$ & $\begin{array}{l}0.0340^{\star} \\
{[0.020]}\end{array}$ & $\begin{array}{l}0.0139 \\
{[0.024]}\end{array}$ & $\begin{array}{c}0.032 \\
{[0.021]}\end{array}$ & $\begin{array}{l}0.0199 \\
{[0.022]}\end{array}$ & $\begin{array}{l}0.0119 \\
{[0.020]}\end{array}$ & $\begin{array}{l}0.0193 \\
{[0.018]}\end{array}$ & $\begin{array}{l}0.0157 \\
{[0.020]}\end{array}$ & $\begin{array}{l}0.0045 \\
{[0.018]}\end{array}$ & $\begin{array}{l}0.0227 \\
{[0.020]}\end{array}$ \\
\hline inequality $\mathrm{x}$ fiscal stimuli & $\begin{array}{l}0.0608 \\
{[0.044]}\end{array}$ & & & & & $\begin{array}{l}0.0031 \\
{[0.033]}\end{array}$ & & & & \\
\hline fiscal stimuli & $\begin{array}{l}-2.312 \\
{[1.413]}\end{array}$ & & & & & $\begin{array}{l}-0.2524 \\
{[1.540]}\end{array}$ & & & & \\
\hline inequality $\mathrm{x}$ increasingly expansionary fiscal stimuli & & $\begin{array}{l}-0.0196 \\
{[0.076]}\end{array}$ & & & & & $\begin{array}{c}-0.0616 \\
{[0.039]}\end{array}$ & & & \\
\hline increasingly expansionary fiscal stimuli & & $\begin{array}{l}0.8821 \\
{[2.652]}\end{array}$ & & & & & $\begin{array}{l}2.2453 \\
{[1.740]}\end{array}$ & & & \\
\hline inequality $\mathrm{x}$ expansionary fiscal stimuli & & & $\begin{array}{l}0.0695^{*} \\
{[0.042]}\end{array}$ & & & & & $\begin{array}{l}-0.0103 \\
{[0.034]}\end{array}$ & & \\
\hline expansionary fiscal stimuli & & & $\begin{array}{c}-2.3538^{*} \\
{[1.422]}\end{array}$ & & & & & $\begin{array}{l}0.3751 \\
{[1.534]}\end{array}$ & & \\
\hline inequality $x$ successful fiscal stimuli & & & & $\begin{array}{l}0.0689 \\
{[0.045]}\end{array}$ & & & & & $\begin{array}{c}0.1417^{\star *} \\
{[0.065]}\end{array}$ & \\
\hline successful fiscal stimuli & & & & $\begin{array}{c}-3.2544^{\star \star} \\
{[1.644]}\end{array}$ & & & & & $\begin{array}{c}-6.4800^{* *} \\
{[3.147]}\end{array}$ & \\
\hline inequality $\mathrm{x}$ unsuccessful fiscal stimuli & & & & & $\begin{array}{l}0.0629 \\
{[0.052]}\end{array}$ & & & & & $\begin{array}{l}-0.0505 \\
{[0.034]}\end{array}$ \\
\hline unsuccesful fiscal stimuli & & & & & $\begin{array}{l}-2.2936 \\
{[1.609]}\end{array}$ & & & & & $\begin{array}{l}1.8934 \\
{[1.537]}\end{array}$ \\
\hline Constant & $\begin{array}{c}-2.6859^{\star * *} \\
{[0.782]}\end{array}$ & $\begin{array}{c}-3.3185^{\star \star \star} \\
{[0.748]}\end{array}$ & $\begin{array}{c}-2.6721^{* * *} \\
{[0.781]}\end{array}$ & $\begin{array}{c}-3.2319^{* * *} \\
{[0.747]}\end{array}$ & $\begin{array}{c}-2.7855^{\star \star *} \\
{[0.745]}\end{array}$ & $\begin{array}{c}-2.3016^{* *} \\
{[0.988]} \\
\end{array}$ & $\begin{array}{c}-2.6266^{* * *} \\
{[0.877]}\end{array}$ & $\begin{array}{c}-2.4824^{* *} \\
{[0.980]} \\
\end{array}$ & $\begin{array}{c}-2.0391^{* *} \\
{[0.851]}\end{array}$ & $\begin{array}{c}-2.7599^{\star * \star \star} \\
{[0.975]}\end{array}$ \\
\hline Observations & 571 & 571 & 571 & 571 & 571 & 689 & 689 & 689 & 678 & 681 \\
\hline & 0.0766 & 0.053 & 0.0394 & 0.031 & 0.0619 & 0.523 & 0.396 & 0.513 & 0.524 & 0.419 \\
\hline Prob $>\chi^{2}$ & 0.782 & 0.818 & 0.843 & 0.86 & 0.803 & 0.469 & 0.529 & 0.474 & 0.469 & 0.517 \\
\hline
\end{tabular}


Table 5: Results with political and institutional controllers.

\begin{tabular}{|c|c|c|c|c|c|}
\hline & (1) & (2) & (3) & (4) & (5) \\
\hline GDP growth rate & $\begin{array}{c}-0.1445^{\star} \\
{[0.081]}\end{array}$ & $\begin{array}{c}-0.1311^{*} \\
{[0.075]}\end{array}$ & $\begin{array}{c}-0.1406^{*} \\
{[0.078]}\end{array}$ & $\begin{array}{c}-0.1358^{*} \\
{[0.076]}\end{array}$ & $\begin{array}{c}-0.1361^{*} \\
{[0.0781}\end{array}$ \\
\hline military & $\begin{array}{l}0.0511 \\
{[0.418]}\end{array}$ & $\begin{array}{l}0.0792 \\
{[0.418]}\end{array}$ & $\begin{array}{l}0.0693 \\
{[0.419]}\end{array}$ & $\begin{array}{l}0.0525 \\
{[0.424]}\end{array}$ & $\begin{array}{l}0.0393 \\
{[0.414]}\end{array}$ \\
\hline stabs & $\begin{array}{c}-0.7567^{* *} \\
{[0.358]}\end{array}$ & $\begin{array}{c}-0.7329^{* *} \\
{[0.361]}\end{array}$ & $\begin{array}{c}-0.7517^{\star \star} \\
{[0.358]}\end{array}$ & $\begin{array}{c}-0.7311^{* *} \\
{[0.366]}\end{array}$ & $\begin{array}{c}-0.7563^{\star \star} \\
{[0.363]}\end{array}$ \\
\hline system & $\begin{array}{c}0.3515^{\star \star} \\
{[0.157]}\end{array}$ & $\begin{array}{c}0.3383^{\star \star} \\
{[0.154]}\end{array}$ & $\begin{array}{c}0.3446^{\star *} \\
{[0.155]}\end{array}$ & $\begin{array}{c}0.3406^{* *} \\
{[0.154]}\end{array}$ & $\begin{array}{c}0.3559^{* *} \\
{[0.156]}\end{array}$ \\
\hline govfrac & $\begin{array}{l}0.3183 \\
{[0.378]}\end{array}$ & $\begin{array}{l}0.3078 \\
{[0.377]}\end{array}$ & $\begin{array}{l}0.3083 \\
{[0.377]}\end{array}$ & $\begin{array}{l}0.3369 \\
{[0.384]}\end{array}$ & $\begin{array}{l}0.2709 \\
{[0.378]}\end{array}$ \\
\hline polity2 & $\begin{array}{c}0.2759^{\star * *} \\
{[0.073]}\end{array}$ & $\begin{array}{c}0.2655^{\star * *} \\
{[0.072]}\end{array}$ & $\begin{array}{c}0.2762^{* * *} \\
{[0.073]}\end{array}$ & $\begin{array}{c}0.2510^{* * *} \\
{[0.074]}\end{array}$ & $\begin{array}{c}0.2732^{\star * \star} \\
{[0.074]}\end{array}$ \\
\hline durable & $\begin{array}{c}-0.0094^{\star * \star} \\
{[0.003]}\end{array}$ & $\begin{array}{c}-0.0088^{\star * *} \\
{[0.003]}\end{array}$ & $\begin{array}{c}-0.0094^{\star \star *} \\
{[0.003]}\end{array}$ & $\begin{array}{c}-0.0089^{* \star \star} \\
{[0.003]}\end{array}$ & $\begin{array}{c}-0.0093^{* \star *} \\
{[0.003]}\end{array}$ \\
\hline polcomp & $\begin{array}{c}-0.3949^{* * *} \\
{[0.135]}\end{array}$ & $\begin{array}{c}-0.3768^{* * *} \\
{[0.134]}\end{array}$ & $\begin{array}{c}-0.3929^{* * *} \\
{[0.135]}\end{array}$ & $\begin{array}{c}-0.3491^{* *} \\
{[0.138]}\end{array}$ & $\begin{array}{c}-0.3882^{* * *} \\
{[0.1371}\end{array}$ \\
\hline yrsoffc & $\begin{array}{l}-0.0388 \\
{[0.026]}\end{array}$ & $\begin{array}{l}-0.0403 \\
{[0.027]}\end{array}$ & $\begin{array}{l}-0.0386 \\
{[0.026]}\end{array}$ & $\begin{array}{c}-0.0386 \\
{[0.027]}\end{array}$ & $\begin{array}{l}-0.0366 \\
{[0.026]}\end{array}$ \\
\hline maj & $\begin{array}{c}-1.0543^{*} \\
{[0.627]}\end{array}$ & $\begin{array}{l}-1.0074 \\
{[0.622]}\end{array}$ & $\begin{array}{c}-1.0436^{*} \\
{[0.627]}\end{array}$ & $\begin{array}{l}-1.0295 \\
{[0.636]}\end{array}$ & $\begin{array}{l}-0.9966 \\
{[0.633]}\end{array}$ \\
\hline party_coal & $\begin{array}{c}-0.4447^{\star * *} \\
{[0.159]}\end{array}$ & $\begin{array}{c}-0.4475^{\star \star *} \\
{[0.159]}\end{array}$ & $\begin{array}{c}-0.4420^{* \star *} \\
{[0.159]}\end{array}$ & $\begin{array}{c}-0.4351^{* * *} \\
{[0.163]}\end{array}$ & $\begin{array}{c}-0.4474^{* * *} \\
{[0.160]}\end{array}$ \\
\hline inequality & $\begin{array}{c}0.0377^{\star *} \\
{[0.015]}\end{array}$ & $\begin{array}{c}0.0363^{\star \star} \\
{[0.015]}\end{array}$ & $\begin{array}{c}0.0372^{* *} \\
{[0.015]}\end{array}$ & $\begin{array}{c}0.0366^{\star *} \\
{[0.015]}\end{array}$ & $\begin{array}{c}0.0365^{\star *} \\
{[0.015]}\end{array}$ \\
\hline fiscal stimuli & $\begin{array}{l}-0.4124 \\
{[0.265]}\end{array}$ & & & & \\
\hline increasingly expansionary fiscal stimuli & & $\begin{array}{l}-0.4351 \\
{[0.385]}\end{array}$ & & & \\
\hline expansionary fiscal stimuli & & & $\begin{array}{l}-0.3842 \\
{[0.255]}\end{array}$ & & \\
\hline successful fiscal stimuli & & & & $\begin{array}{l}-0.0027 \\
{[0.352]}\end{array}$ & \\
\hline unsuccesful fiscal stimuli & & & & & $\begin{array}{c}-0.4907^{*} \\
{[0.278]}\end{array}$ \\
\hline Constant & $\begin{array}{l}0.0884 \\
{[1.226]}\end{array}$ & $\begin{array}{l}-0.0454 \\
{[1.218]}\end{array}$ & $\begin{array}{l}0.0638 \\
{[1.227]}\end{array}$ & $\begin{array}{l}-0.2626 \\
{[1.232]}\end{array}$ & $\begin{array}{l}0.0311 \\
{[1.226]}\end{array}$ \\
\hline Observations & 1,068 & 1,068 & 1,068 & 1,058 & 1,061 \\
\hline$\chi^{2}$ & 0.0011 & 0.0036 & 0.000861 & 0.00366 & 0.00307 \\
\hline Prob $>\chi^{2}$ & 0.974 & 0.952 & 0.977 & 0.952 & 0.956 \\
\hline
\end{tabular}


Table 6: Results with political and institutional controllers: OECD versus non-OECD countries.

OECD countries

non-OECD countries

\begin{tabular}{|c|c|c|c|c|c|c|c|c|c|c|}
\hline & & \\
\hline & (1) & (2) & (3) & (4) & (5) & $(1)$ & $(2)$ & (3) & (4) & (5) \\
\hline \multirow[t]{2}{*}{ GDP growth rate } & $-0.2943^{*}$ & -0.2596 & $-0.2746^{\star}$ & -0.2503 & $-0.3044^{*}$ & -0.0962 & -0.0909 & -0.0985 & -0.0889 & -0.0891 \\
\hline & {$[0.174]$} & {$[0.162]$} & {$[0.164]$} & [0.153] & {$[0.177]$} & {$[0.101]$} & {$[0.094]$} & [0.098] & [0.098] & {$[0.096]$} \\
\hline \multirow[t]{2}{*}{ military } & $-8.0639^{* * *}$ & $-8.3541^{* * *}$ & $-8.1899^{\star * \star}$ & $-8.0878^{* * *}$ & $-8.2975^{\star \star \star}$ & 0.0616 & 0.1091 & 0.0814 & 0.0771 & 0.0546 \\
\hline & [1.238] & [1.114] & [1.174] & [1.249] & [1.142] & {$[0.412]$} & {$[0.408]$} & {$[0.412]$} & {$[0.417]$} & {$[0.407]$} \\
\hline \multirow[t]{2}{*}{ stabs } & $-1.0636^{*}$ & -0.9773 & $-1.0480^{*}$ & -0.9879 & $-1.0659^{*}$ & -0.6919 & -0.7029 & -0.6966 & -0.6561 & -0.6931 \\
\hline & {$[0.611]$} & {$[0.610]$} & {$[0.611]$} & {$[0.604]$} & {$[0.611]$} & [0.462] & {$[0.464]$} & {$[0.459]$} & {$[0.471]$} & [0.472] \\
\hline \multirow[t]{2}{*}{ system } & $0.9887^{*}$ & $0.9154^{*}$ & $0.9769^{*}$ & $0.9495^{*}$ & $0.9548^{*}$ & 0.1091 & 0.1077 & 0.1021 & 0.0939 & 0.1101 \\
\hline & {$[0.505]$} & {$[0.487]$} & {$[0.504]$} & [0.499] & [0.497] & [0.197] & {$[0.194]$} & [0.193] & {$[0.195]$} & {$[0.194]$} \\
\hline \multirow[t]{2}{*}{ govfrac } & 0.2413 & 0.3475 & 0.2754 & 0.3275 & 0.2457 & 0.5079 & 0.5002 & 0.4965 & 0.5285 & 0.4373 \\
\hline & {$[0.778]$} & {$[0.786]$} & [0.782] & {$[0.791]$} & {$[0.778]$} & {$[0.486]$} & {$[0.481]$} & {$[0.485]$} & [0.495] & {$[0.488]$} \\
\hline \multirow[t]{2}{*}{ polity2 } & $1.3479^{\star *}$ & $1.4000^{\star \star \star}$ & $1.3562^{\star *}$ & $1.3699^{*}$ & $1.3822^{* \star}$ & $0.1985^{\star \star \star}$ & $0.2020^{\star * \star}$ & $0.2009^{\star * \star}$ & $0.1860^{* *}$ & $0.2031^{\star \star *}$ \\
\hline & {$[0.664]$} & {$[0.704]$} & {$[0.679]$} & {$[0.700]$} & {$[0.664]$} & {$[0.074]$} & {$[0.074]$} & [0.074] & {$[0.075]$} & {$[0.075]$} \\
\hline \multirow[t]{2}{*}{ durable } & $-0.0149^{\star \star \star}$ & $-0.0146^{\star \star \star}$ & $-0.0148^{\star \star \star *}$ & $-0.0145^{\star \star \star}$ & $-0.0149^{\star \star \star *}$ & -0.0008 & -0.0009 & -0.0011 & -0.0006 & -0.0013 \\
\hline & [0.004] & [0.004] & [0.004] & [0.004] & [0.004] & {$[0.007]$} & {$[0.007]$} & {$[0.007]$} & {$[0.007]$} & [0.007] \\
\hline \multirow[t]{2}{*}{ polcomp } & -0.8528 & -0.7881 & -0.8288 & -0.7958 & -0.839 & $-0.2567^{\star}$ & $-0.2627^{*}$ & $-0.2588^{*}$ & -0.2375 & $-0.2620^{*}$ \\
\hline & {$[0.536]$} & {$[0.568]$} & {$[0.543]$} & [0.563] & [0.543] & {$[0.149]$} & {$[0.150]$} & {$[0.149]$} & {$[0.153]$} & [0.152] \\
\hline \multirow{2}{*}{ yrsoffc } & -0.0467 & -0.0489 & -0.0457 & -0.0457 & -0.0511 & $-0.0468^{*}$ & $-0.0466^{*}$ & $-0.0464^{*}$ & -0.0451 & -0.0435 \\
\hline & {$[0.063]$} & [0.063] & {$[0.063]$} & {$[0.063]$} & {$[0.064]$} & {$[0.027]$} & {$[0.027]$} & {$[0.027]$} & {$[0.028]$} & {$[0.027]$} \\
\hline \multirow[t]{2}{*}{ maj } & 0.3182 & 0.3793 & 0.3728 & 0.4778 & 0.2618 & $-1.3427^{* *}$ & $-1.3116^{\star *}$ & $-1.3463^{* *}$ & $-1.3369^{* *}$ & $-1.2650^{\star}$ \\
\hline & [1.474] & [1.480] & [1.472] & [1.472] & [1.485] & [0.645] & [0.643] & [0.645] & [0.659] & [0.651] \\
\hline \multirow[t]{2}{*}{ party_coal } & -0.6547 & -0.6471 & -0.6474 & -0.6396 & -0.6626 & $-0.4982^{\star \star \star *}$ & $-0.4927^{* * *}$ & $-0.4933^{\star * *}$ & $-0.4860^{\star \star *}$ & $-0.4913^{* * *}$ \\
\hline & {$[0.413]$} & {$[0.416]$} & {$[0.415]$} & {$[0.418]$} & {$[0.412]$} & {$[0.169]$} & {$[0.168]$} & [0.169] & {$[0.175]$} & {$[0.170]$} \\
\hline \multirow[t]{2}{*}{ inequality } & $0.1282^{\star \star \star}$ & $0.1279^{\star \star \star}$ & $0.1288^{\star * \star}$ & $0.1291^{\star * \star}$ & $0.1275^{\star \star \star}$ & -0.0038 & -0.0041 & -0.0044 & -0.0031 & -0.0036 \\
\hline & [0.039] & {$[0.040]$} & [0.039] & {$[0.040]$} & [0.039] & {$[0.018]$} & {$[0.018]$} & {$[0.018]$} & {$[0.019]$} & {$[0.018]$} \\
\hline fiscal stimuli & $\begin{array}{l}-0.7046 \\
{[0.4581}\end{array}$ & & & & & -0.2632 & & & & \\
\hline increasingly expansionary fiscal stimuli & & 0.1513 & & & & ] & $-0.7871^{*}$ & & & \\
\hline expansionary fiscal stimuli & & & $\begin{array}{l}-0.4935 \\
{[0.426]}\end{array}$ & & & & {$[0.450]$} & $\begin{array}{c}-0.3382 \\
{[0.3001}\end{array}$ & & \\
\hline successful fiscal stimuli & & & & $\begin{array}{l}-0.7541 \\
{[0.632]}\end{array}$ & & & & & $\begin{array}{l}0.1966 \\
{[0.382]}\end{array}$ & \\
\hline unsuccesful fiscal stimuli & & & & & $\begin{array}{l}-0.6358 \\
{[0.477]}\end{array}$ & & & & & $\begin{array}{l}-0.486 \\
{[0.342]}\end{array}$ \\
\hline Constant & $\begin{array}{c}-9.4967^{* *} \\
{[4.716]}\end{array}$ & $\begin{array}{c}-10.8178^{* *} \\
{[4.779]}\end{array}$ & $\begin{array}{c}-9.9692^{* *} \\
{[4.738]}\end{array}$ & $\begin{array}{c}-10.6280^{* *} \\
{[4.749]}\end{array}$ & $\begin{array}{c}-9.8165^{\star \star} \\
{[4.748]}\end{array}$ & $\begin{array}{c}1.6968 \\
{[1.361]}\end{array}$ & $\begin{array}{r}1.6991 \\
{[1.364]}\end{array}$ & $\begin{array}{l}1.7448 \\
{[1.364]}\end{array}$ & $\begin{array}{c}1.407 \\
{[1.389]}\end{array}$ & $\begin{array}{l}1.6404 \\
{[1.368]}\end{array}$ \\
\hline Observations & 494 & 494 & 494 & 494 & 494 & 574 & 574 & 574 & 564 & 567 \\
\hline$\chi^{2}$ & 0.345 & 0.392 & 0.319 & 0.243 & 0.493 & 0.103 & 0.171 & 0.0849 & 0.106 & 0.173 \\
\hline Prob $>\chi^{2}$ & 0.557 & 0.531 & 0.572 & 0.622 & 0.482 & 0.748 & 0.679 & 0.771 & 0.744 & 0.677 \\
\hline
\end{tabular}


Table 7: Results with political and institutional controllers and interactions between inequality and fiscal stimuli.

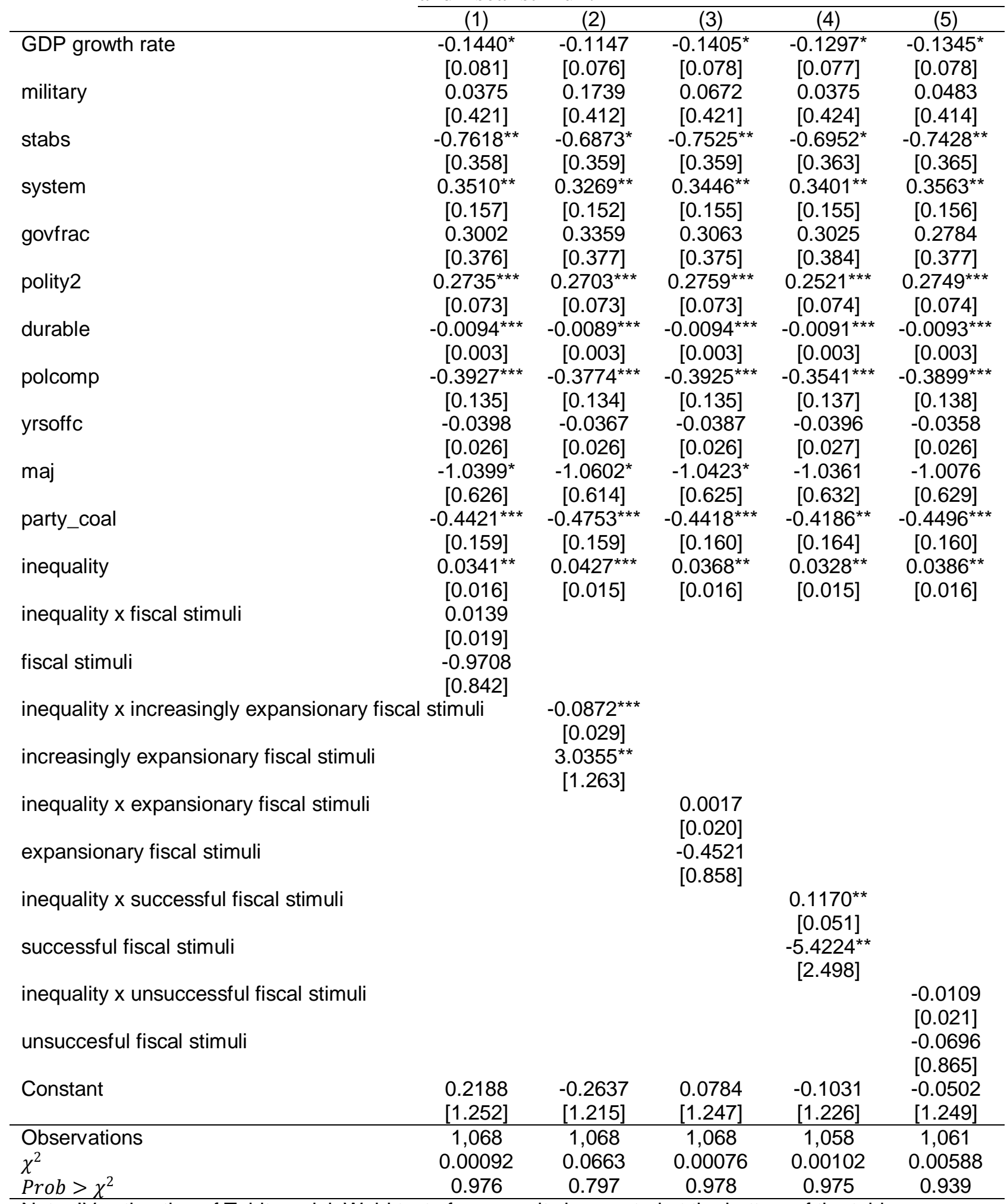

Note: IV estimation of Tobit model. Wald test of exogeneity is reported at the bottom of the table..

Robust standard errors in brackets. ${ }^{* \star} \mathrm{p}<0.01,{ }^{* \star} p<0.05,{ }^{*} p<0.1$. 
Table 8: Results with political and institutional controllers and interactions between inequality and fiscal stimuli: OECD versus non-OECD countries. OECD countries

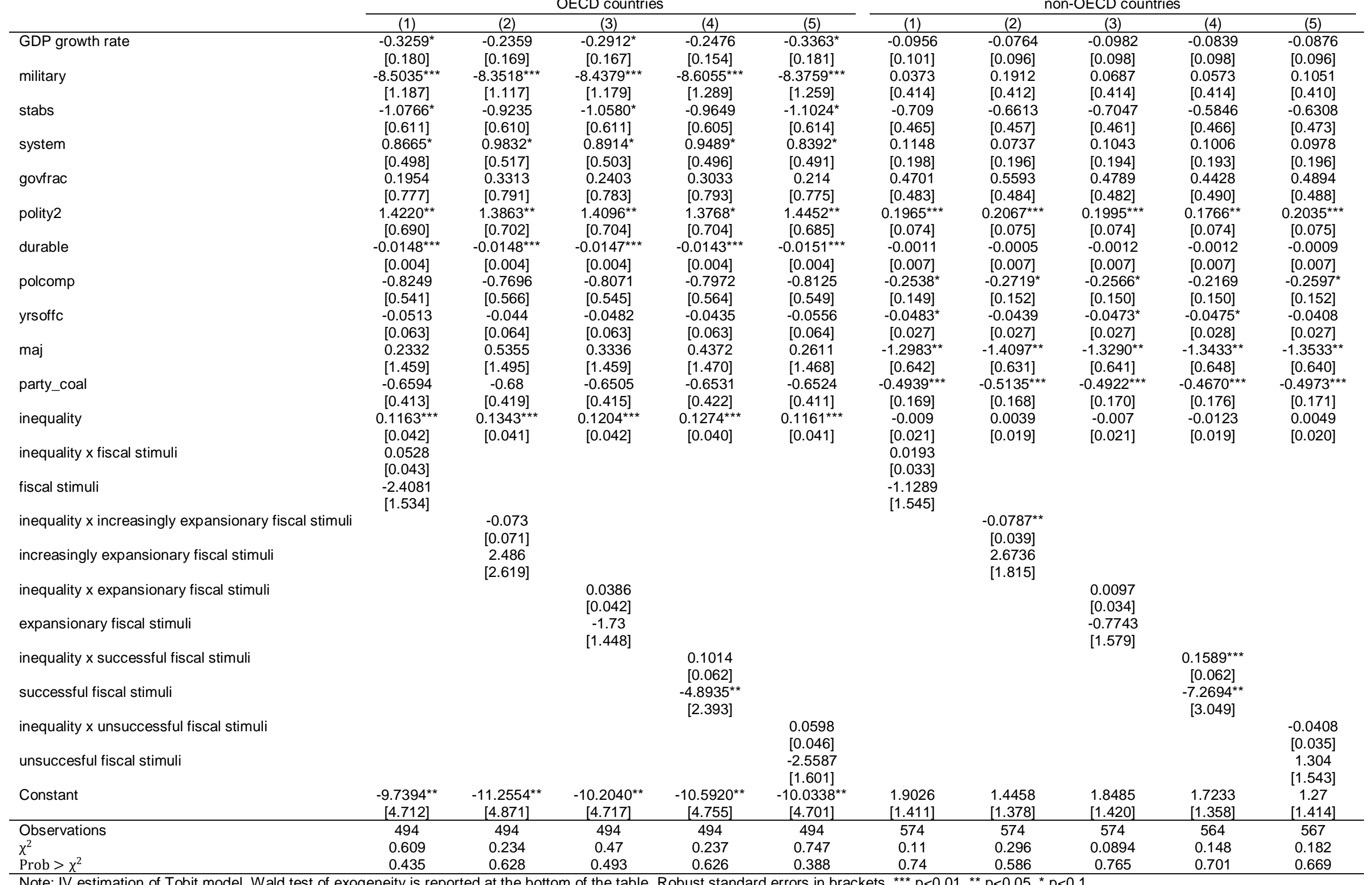


Table 9: Regional analysis I.

\begin{tabular}{|c|c|c|c|c|c|c|c|c|c|c|}
\hline & \multicolumn{5}{|c|}{ Europe } & \multicolumn{5}{|c|}{ North America } \\
\hline & $(1)$ & $(2)$ & (3) & $(4)$ & $(5)$ & $(1)$ & $(2)$ & (3) & $(4)$ & $(5)$ \\
\hline GDP growth rate & $\begin{array}{c}-0.2431^{* *} \\
{[0.098]}\end{array}$ & $\begin{array}{c}-0.2234^{* *} \\
{[0.097]}\end{array}$ & $\begin{array}{c}-0.2361^{\star *} \\
{[0.096]}\end{array}$ & $\begin{array}{c}-0.2177^{\star *} \\
{[0.090]}\end{array}$ & $\begin{array}{c}-0.2322^{* *} \\
{[0.098]}\end{array}$ & $\begin{array}{c}-0.3912 \\
{[0.609]}\end{array}$ & $\begin{array}{c}-0.1536 \\
{[0.340]}\end{array}$ & $\begin{array}{c}-0.3912 \\
{[0.609]}\end{array}$ & $\begin{array}{c}-0.5706 \\
{[0.414]}\end{array}$ & $\begin{array}{c}-0.1151 \\
{[0.317]}\end{array}$ \\
\hline inequality & $\begin{array}{c}0.1436^{\star \star \star} \\
{[0.028]}\end{array}$ & $\begin{array}{c}0.1331^{\star \star *} \\
{[0.027]}\end{array}$ & $\begin{array}{c}0.1436^{\star \star \star} \\
{[0.028]}\end{array}$ & $\begin{array}{c}0.1368^{\star \star \star} \\
{[0.027]}\end{array}$ & $\begin{array}{c}0.1355^{\star \star \star} \\
{[0.027]}\end{array}$ & $\begin{array}{c}-0.8320^{\star *} \\
{[0.360]}\end{array}$ & $\begin{array}{c}-0.8606^{* *} \\
{[0.368]}\end{array}$ & $\begin{array}{c}-0.8320^{\star *} \\
{[0.360]}\end{array}$ & $\begin{array}{c}-0.4608^{\star *} \\
{[0.223]}\end{array}$ & $\begin{array}{c}-0.7455^{\star \star} \\
{[0.366]}\end{array}$ \\
\hline fiscal stimuli & $\begin{array}{c}-0.8381^{*} \\
{[0.447]}\end{array}$ & & & & & $\begin{array}{l}1.5148 \\
{[1.847]}\end{array}$ & & & & \\
\hline increasingly expansionary fiscal stimuli & & $\begin{array}{l}-0.6644 \\
{[0.804]}\end{array}$ & & & & & $\begin{array}{c}2.5359^{*} \\
{[1.298]}\end{array}$ & & & \\
\hline expansionary fiscal stimuli & & & $\begin{array}{c}-0.7691^{*} \\
{[0.443]}\end{array}$ & & & & & $\begin{array}{l}1.5148 \\
{[1.847]}\end{array}$ & & \\
\hline successful fiscal stimuli & & & & $\begin{array}{c}-1.5150^{*} \\
{[0.807]}\end{array}$ & & & & & $\begin{array}{c}-4.0901^{\star *} \\
{[2.011]}\end{array}$ & \\
\hline unsuccesful fiscal stimuli & & & & & $\begin{array}{l}-0.6115 \\
{[0.432]}\end{array}$ & & & & & $\begin{array}{c}2.6088^{\star *} \\
{[1.307]}\end{array}$ \\
\hline Constant & $\begin{array}{c}-5.7248^{\star \star *} \\
{[0.935]}\end{array}$ & $\begin{array}{c}-5.5951^{\star * *} \\
{[0.908]}\end{array}$ & $\begin{array}{c}-5.7589^{\star * \star} \\
{[0.937]}\end{array}$ & $\begin{array}{c}-5.6992^{\star * \star} \\
{[0.924]}\end{array}$ & $\begin{array}{c}-5.5641^{\star * \star} \\
{[0.925]}\end{array}$ & $\begin{array}{l}23.122^{\star *} \\
{[10.402]}\end{array}$ & $\begin{array}{l}23.430^{\star *} \\
{[10.360]}\end{array}$ & $\begin{array}{l}23.122^{\star *} \\
{[10.402]}\end{array}$ & $\begin{array}{l}12.541^{*} \\
{[6.574]}\end{array}$ & $\begin{array}{l}20.086^{\star \star} \\
{[10.214]}\end{array}$ \\
\hline Observations & 449 & 449 & 449 & 448 & 448 & 72 & 72 & 72 & 72 & 72 \\
\hline & 0.95 & 1.123 & 0.919 & 0.684 & 1.033 & 0.856 & 0.886 & 0.856 & 0.342 & 0.92 \\
\hline Prob $>\chi^{2}$ & 0.33 & 0.289 & 0.338 & 0.408 & 0.31 & 0.355 & 0.347 & 0.355 & 0.559 & 0.337 \\
\hline
\end{tabular}


Table 10: Regional analysis II.

\begin{tabular}{|c|c|c|c|c|c|c|c|c|c|c|c|c|c|c|c|}
\hline & \multicolumn{5}{|c|}{ APAC } & \multicolumn{5}{|c|}{ Latin America } & \multicolumn{5}{|c|}{ Africa } \\
\hline & (1) & (2) & (3) & (4) & (5) & (1) & (2) & (3) & (4) & (5) & (1) & (2) & (3) & (4) & (5) \\
\hline GDP growth rate & $\begin{array}{l}0.1013 \\
{[0.159]}\end{array}$ & $\begin{array}{l}0.1044 \\
{[0.158]}\end{array}$ & $\begin{array}{l}0.0984 \\
{[0.150]}\end{array}$ & $\begin{array}{l}0.0802 \\
{[0.151]}\end{array}$ & $\begin{array}{l}0.1265 \\
{[0.167]}\end{array}$ & $\begin{array}{l}-0.2052 \\
{[0.125]}\end{array}$ & $\begin{array}{c}-0.2148^{*} \\
{[0.115]}\end{array}$ & $\begin{array}{c}-0.2102^{*} \\
{[0.120]}\end{array}$ & $\begin{array}{c}-0.1956^{*} \\
{[0.110]}\end{array}$ & $\begin{array}{c}-0.2347^{\star *} \\
{[0.118]}\end{array}$ & $\begin{array}{l}-0.0486 \\
{[0.146]}\end{array}$ & $\begin{array}{c}-0.0343 \\
{[0.149]}\end{array}$ & $\begin{array}{l}-0.0344 \\
{[0.144]}\end{array}$ & $\begin{array}{l}-0.0378 \\
{[0.145]}\end{array}$ & $\begin{array}{l}-0.0509 \\
{[0.154]}\end{array}$ \\
\hline inequality & $\begin{array}{l}0.0069 \\
{[0.033]}\end{array}$ & $\begin{array}{c}0.007 \\
{[0.032]}\end{array}$ & $\begin{array}{l}0.0071 \\
{[0.032]}\end{array}$ & $\begin{array}{l}0.0153 \\
{[0.033]}\end{array}$ & $\begin{array}{l}0.0047 \\
{[0.033]}\end{array}$ & $\begin{array}{l}0.0233 \\
{[0.045]}\end{array}$ & $\begin{array}{l}0.0225 \\
{[0.046]}\end{array}$ & $\begin{array}{l}0.0234 \\
{[0.046]}\end{array}$ & $\begin{array}{l}0.0226 \\
{[0.045]}\end{array}$ & $\begin{array}{l}0.0211 \\
{[0.046]}\end{array}$ & $\begin{array}{l}0.0423 \\
{[0.039]}\end{array}$ & $\begin{array}{l}0.0422 \\
{[0.041]}\end{array}$ & $\begin{array}{l}0.0451 \\
{[0.039]}\end{array}$ & $\begin{array}{l}0.0439 \\
{[0.041]}\end{array}$ & $\begin{array}{l}0.0392 \\
{[0.041]}\end{array}$ \\
\hline fiscal stimuli & $\begin{array}{l}0.0361 \\
{[0.570]}\end{array}$ & & & & & $\begin{array}{l}-0.0355 \\
{[0.444]}\end{array}$ & & & & & $\begin{array}{l}-0.705 \\
{[0.707]}\end{array}$ & & & & \\
\hline increasingly expansionary fiscal stimuli & & $\begin{array}{l}0.3444 \\
{[0.931]}\end{array}$ & & & & & $\begin{array}{c}-0.6326 \\
{[0.529]}\end{array}$ & & & & & $\begin{array}{l}0.1554 \\
{[1.050]}\end{array}$ & & & \\
\hline expansionary fiscal stimuli & & & $\begin{array}{c}0.178 \\
{[0.558]}\end{array}$ & & & & & $\begin{array}{l}-0.0507 \\
{[0.402]}\end{array}$ & & & & & $\begin{array}{l}-0.5121 \\
{[0.704]}\end{array}$ & & \\
\hline successful fiscal stimuli & & & & $\begin{array}{l}-0.4621 \\
{[1.033]}\end{array}$ & & & & & $\begin{array}{l}0.5607 \\
{[0.479]}\end{array}$ & & & & & $\begin{array}{l}-0.4758 \\
{[0.935]}\end{array}$ & \\
\hline unsuccesful fiscal stimuli & & & & & $\begin{array}{l}0.1827 \\
{[0.634]}\end{array}$ & & & & & $\begin{array}{l}-0.5558 \\
{[0.457]}\end{array}$ & & & & & $\begin{array}{l}-0.7165 \\
{[0.9811}\end{array}$ \\
\hline Constant & $\begin{array}{c}-2.3580^{* *} \\
{[1.084]}\end{array}$ & $\begin{array}{c}-2.3836^{* *} \\
{[1.079]}\end{array}$ & $\begin{array}{c}-2.3768^{\star *} \\
{[1.080]}\end{array}$ & $\begin{array}{c}-2.6116^{\star *} \\
{[1.111]}\end{array}$ & $\begin{array}{c}-2.3661^{\star *} \\
{[1.098]}\end{array}$ & $\begin{array}{l}-2.5816 \\
{[2.154]} \\
\end{array}$ & $\begin{array}{l}-2.4828 \\
{[2.206]}\end{array}$ & $\begin{array}{l}-2.5786 \\
{[2.174]} \\
\end{array}$ & $\begin{array}{c}-2.6375 \\
{[2.183]} \\
\end{array}$ & $\begin{array}{l}-2.3387 \\
{[2.200]}\end{array}$ & $\begin{array}{c}-4.4464^{* *} \\
{[1.940]}\end{array}$ & $\begin{array}{c}-4.6936^{\star *} \\
{[1.987]}\end{array}$ & $\begin{array}{c}-4.6764^{* *} \\
{[1.913]}\end{array}$ & $\begin{array}{c}-4.6959^{* *} \\
{[1.950]}\end{array}$ & $\begin{array}{c}-4.3915^{\star *} \\
{[2.021]}\end{array}$ \\
\hline Observations & 225 & 225 & 225 & 215 & 218 & 317 & 317 & 317 & 317 & 317 & 150 & 150 & 150 & 150 & 150 \\
\hline & 0.963 & 0.97 & 0.972 & 0.726 & 1.129 & 0.47 & 0.563 & 0.536 & 0.519 & 0.785 & 0.0842 & 0.144 & 0.142 & 0.119 & 0.0784 \\
\hline Prob $>\chi^{2}$ & 0.326 & 0.325 & 0.324 & 0.394 & 0.288 & 0.493 & 0.453 & 0.464 & 0.471 & 0.375 & 0.772 & 0.704 & 0.707 & 0.73 & 0.78 \\
\hline
\end{tabular}




\section{Appendix}

Table A.1: Descriptive statistics.

\begin{tabular}{lcccc}
\hline Variable & Source & Obs & Mean & Std. Dev. \\
\hline Government crises & CNTS & 5878 & 0.16 & 0.51 \\
Real GDP growth rate & WEO & 8658 & 2.34 & 29.11 \\
Inequality & SWIID & 2503 & 37.97 & 10.55 \\
military & DPI & 5646 & 0.20 & 0.40 \\
stabs & DPI & 5377 & 0.12 & 0.28 \\
system & DPI & 5650 & 0.78 & 0.92 \\
govfrac & POLITY IV & 4800 & 0.19 & 0.27 \\
polity2 & POLITY IV & 6192 & 0.92 & 7.48 \\
durable & DPI & 6229 & 22.03 & 28.90 \\
polcomp & POLITY IV & 6010 & 5.46 & 3.72 \\
yrsoffc & DPI & 5658 & 7.39 & 7.62 \\
maj & DPI & 4797 & 0.71 & 0.22 \\
party_coal & DPI & 5619 & 1.57 & 1.26 \\
\hline
\end{tabular}

